\title{
From Poverty to Disaster and Back: a Review of the Literature
}

\section{Stéphane Hallegatte ${ }^{1}$ (D) Adrien Vogt-Schilb ${ }^{2} \cdot$ Julie Rozenberg $^{1} \cdot$ Mook Bangalore $^{1}$. Chloé Beaudet ${ }^{1}$}

Received: 17 January 2020 / Accepted: 4 February 2020 / Published online: 24 April 2020

(C) International Bank for Reconstruction and Development/The World Bank 2020

\begin{abstract}
Poor people are disproportionally affected by natural hazards and disasters. This paper provides a review of the multiple factors that explain why this is the case. It explores the role of exposure (often, but not always, poor people are more likely to be affected by hazards), vulnerability (when they are affected, poor people tend to lose a larger fraction of their wealth), and socio-economic resilience (poor people have a lower ability to cope with and recover from disaster impacts). Finally, the paper highlights the vicious circle between poverty and disaster losses: poverty is a major driver of people's vulnerability to natural disasters, which in turn increase poverty in a measurable and significant way. The main policy implication is that poverty reduction can be considered as disaster risk management, and disaster risk management can be considered as poverty reduction.
\end{abstract}

Keywords Poverty $\cdot$ Disasters $\cdot$ Risk $\cdot$ Climate change

\section{Introduction}

In many ways, it is obvious that poor people are disproportionally affected by natural disasters. Almost by definition, poor people are more vulnerable to shocks, regardless of their origin: because they are poor, any impact on their asset or consumption level threaten subsistence and long-term prospects, and they have less resources to reduce risks or cope with the shock when it occurs.

However, to guide policies and better prioritize action to manage natural hazards, it is useful to go beyond the generic statement ("poor people are disproportionally affected") and investigate the various factors that make poor people more vulnerable. Is it because they are more

Stéphane Hallegatte shallegatte@worldbank.org

1 The World Bank, Washington, DC, USA

2 The Inter-American Development Bank, Washington, DC, USA 
likely to live in place affected by natural hazards? Is it because they are experiencing larger losses when they are affected? Is it because they struggle to replace the lost assets?

This paper builds on recent World Bank reports (Hallegatte et al. 2016c, b, c, 2018) and investigates these questions to identify the main drivers of the relatively higher vulnerability of poor people. It does so by mobilizing the standard framework for risk assessments, which focuses on: (i) hazard - the probability of an event occurring; (ii) exposure - the population and assets located in an affected area; (iii) asset vulnerability - the asset value lost when affected by a hazard.

But this paper goes beyond these traditional factors, which describe the risk to assets - that is, the average monetary value of the damages that disasters inflict on assets (often measured as replacement or repair value) and other direct impacts of disasters. To better understand the impact of natural hazards on people's well-being, this paper extends risk assessment to include the ability of the affected population to cope with and recover from disaster losses. After all, experiencing asset losses is not so much of a problem, if the affected people can easily and painlessly replace the lost assets and move on with their lives. In the rest of this paper, this ability will be referred to as "socioeconomic resilience" and will play a key role in explaining why poor people are disproportionally affected by natural disasters (Fig. 1).

The next section reviews evidence that poor people are often more exposed to natural hazards than the rest of the population. Then, the paper turns to vulnerability and shows poor people are always more vulnerable to disasters. Then it introduces the concept of socioeconomic resilience and the factors that contribute to the lower capacity of poor people to respond and bounce back after natural disasters. The papers finally describes the vicious cycles that keep people in poverty due to natural disasters.

\section{Exposure Bias: Are Poor People more Often Affected by Natural Hazards?}

\section{The Economic Factors Pushing People to Risky Areas}

Poor people are more often affected by natural hazards because they often have to settle in risky areas, for two major reasons. First, at risk areas may be more attractive when they offer economic opportunities, public services or direct amenities, and higher productivity and incomes (Hallegatte 2012). For example, households in regularly flooded areas of Mumbai report that they are aware of the flood risks but accept them because of the opportunities offered by the area such as access to jobs, schools, health care facilities, and social networks (Patankar 2015). Globally, there has been a trend toward increased risk taking: from 1970 to

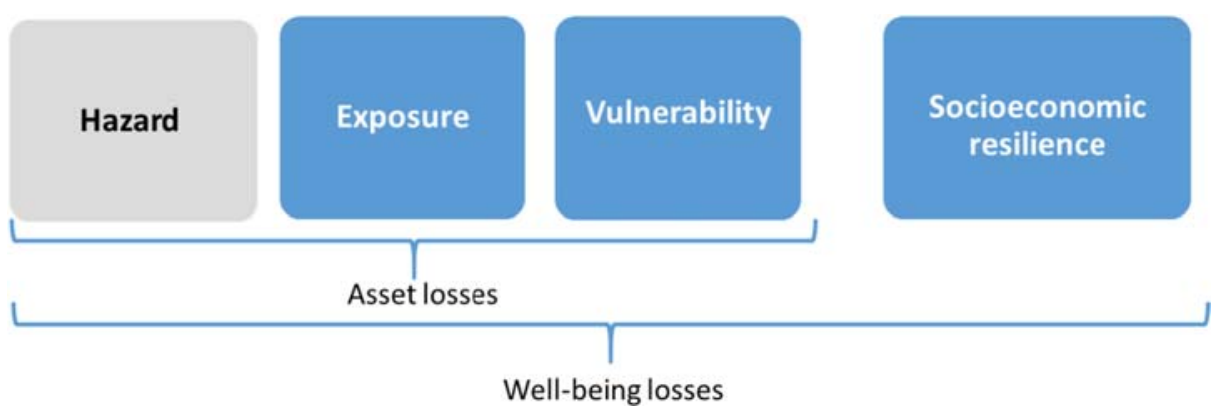

Fig. 1 A comprehensive framework to understand the impact of natural hazards on well-being 
2010 the world population grew by $87 \%$, while the population in flood plains increased by $114 \%$ and in cyclone-prone coastlines by $192 \%$. Risky areas thus attract all kind of population, including poor people.

However, on a more local scale and especially in urban areas, land and housing markets often push poorer people to settle in riskier areas, especially where land is scarce. Indeed, atrisk areas can be much cheaper: a meta-analysis of the literature suggests that a 1 percentage point increase in the yearly probability of flooding is associated with a $0.6 \%$ decrease in housing prices (Daniel et al. 2009). Moreover, in developing countries with informal markets, land scarcity can be particularly acute and land markets function poorly, so the availability of land with appropriate access to jobs and services may push poorer people into risky places (Durand-Lasserve et al. 2013). The effect may also depend on the intensity and rarity of the event: during the exceptional 2015 flood in Accra, Ghana, poor and rich households were as likely to be affected (Erman et al. 2020, see Fig. 2); but for the frequent and recurrent floods that occur in Dar es Salaam, Tanzania, there is evidence that poor people are more likely to be affected (Erman et al. 2019). This difference is probably due to the fact that richer people move away from places that are repeatedly affected but may not be able to escape flood risks completely (either because they do not know they can be affected by an exceptional flood or because it would be too expensive to do so).

Second, poor people benefit less from protection against hazards, mainly because of the lack of infrastructure to protect them. Figure 3 shows that that people in low-income countries - especially those with GDP per capita of less than $\$ 5000$ in purchasing power parity (PPP) exchange rates — are significantly less protected than those in richer countries. This difference in protection alone can explain a factor of 100 in flood risks between poor and rich countries before population vulnerability is considered. The difference is also true within countries: investments - including those in disaster risk reduction-are often directed toward the relatively wealthier areas at the expense of poorer neighborhoods. This effect can stem from the decision-making frameworks: for example, a cost-benefit analysis of flood management investments would favor policies that protect higher-value assets rather than less

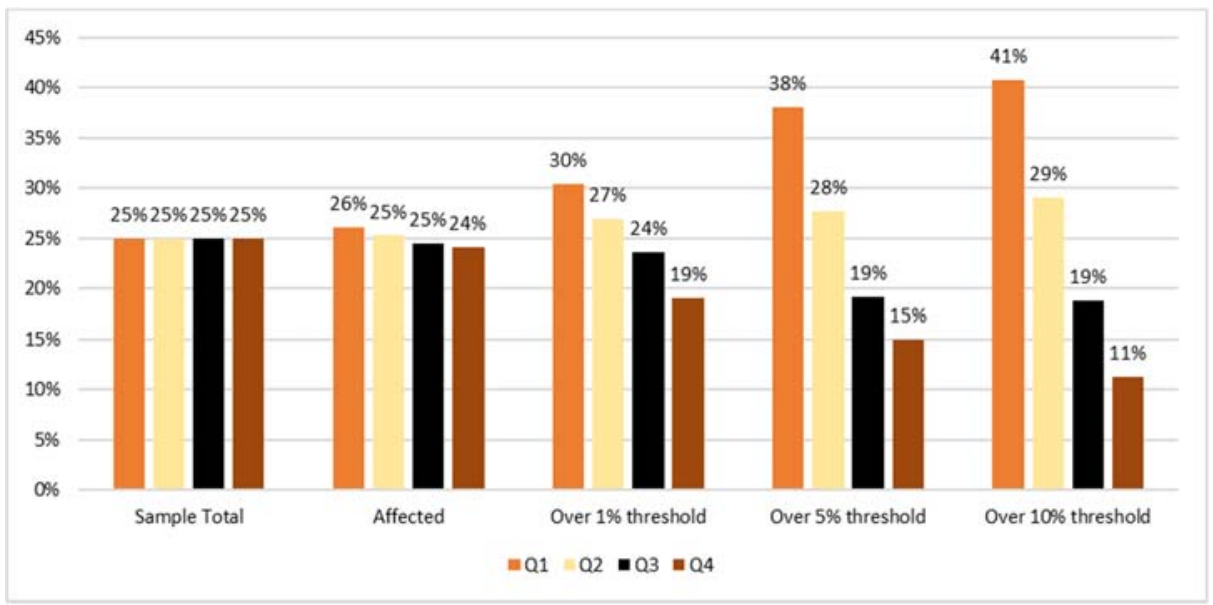

Fig. 2 Distribution of households in Accra, Ghana, over quartiles among (i) entire population, (ii) among households affected by the 2015 floods, (iii, iv, v) among households that lost more than 1\%, 5\% and $10 \%$ of their annual household expenditure in the 2015 floods. Source: Erman et al. (2020) 


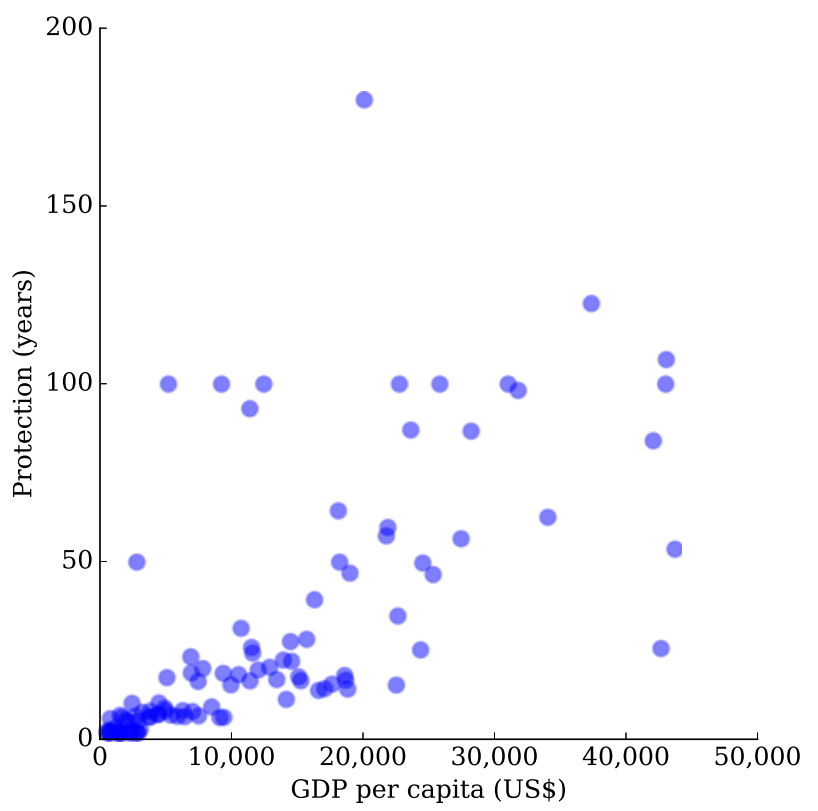

Fig. 3 Protection level as a function of GDP per capita, PPP-adjusted, by return period. Source: Scussolini et al. 2016, Note: PPP = purchasing power parity. Figure shows protection level from FLOPROS (FLOod PROtection Standards, a global open and collaborative database) as a function of GDP per capita. A 100-year protection level means that the protection can prevent all floods that are more frequent than the 100-year flood (that is, all floods with an annual probability of occurrence higher than 1\%). Each dot represents a country. The y-axis is truncated at 200 years. A few countries in the database have higher protection levels such as the Netherlands (more than 4000 years)

productive one. Explicit choices to support poor communities are thus necessary to ensure that risk management policies support communities with the least adaptive capacities.

\section{Exposure Bias in Past Disasters}

At the local level and based on past disasters, poor people seem more likely to be affected by natural disasters. After Cyclone Aila hit Bangladesh in 2009, a postdisaster survey of 12 villages on the southwest coast found that $25 \%$ of poor households in these villages were exposed to the cyclone, whereas only $14 \%$ of nonpoor households were (Akter and Mallick 2013). However, this pattern is not universal. Most studies find that poor people are more exposed (Fig. 4), but the relationship between poverty and disaster exposure depends on the type of hazard, local geography, institutions, and other mechanisms.

For example, Narloch and Bangalore (2016) find that in Vietnam the overexposure of poor to floods is limited to urban households (Fig. 5), an environment where land scarcity can push the poor toward the high-risk areas that richer households prefer to avoid. Bangalore et al. (2019) find that a higher percentage of the potential slum areas are exposed to floods (69\% for a 10-year return period) compared to the urban area as a whole (63\% for a 10-year return period). In rural areas, more abundant land (and possibly the benefits of floods for agricultural production) may explain why poor people are not systematically overexposed (Hallegatte et al. 2016c, b, c).

This overexposure is likely to increase as population and climate change over time. (Bangalore et al. 2019) find that $70 \%$ of urban expansion areas is prone to flooding. This is 


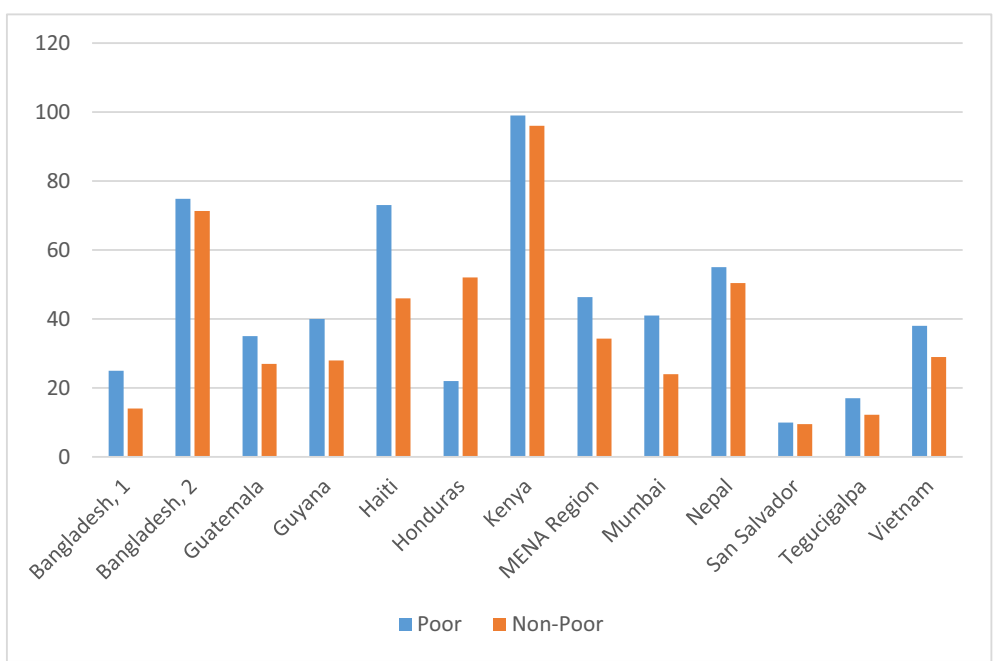

Fig. 4 Percent of poor and nonpoor affected by natural hazards, selected countries. Sources: Bangadesh 1: Akter and Mallick 2013; Bangladesh 2: del Ninno et al. 2001; Guatemala: Tesliuc and Lindert 2003; Guyana: Pelling 1997; Haiti: Fuchs 2014; Honduras: Carter et al. 2007; Kenya: Opondo 2013; MENA: Wodon et al. 2014; Mumbai: Baker et al. 2005, Ranger et al. 2011; Nepal: Gentle et al. 2014; San Salvador and Tegucigalpa: Fay 2005; Vietnam: Nguyen 2011. Note: MENA = Middle East and North Africa. Each study has a different definition of "poor" and "nonpoor" people. The definition of exposure differs based on the type of hazard and context in which it occurs

consistent with the idea that urbanization takes place first in safer areas and then extends toward riskier areas as urban population growth, economic growth, and climate change increase land scarcity (Hallegatte 2014).

\section{Current Exposure Bias}

The Shock Waves report by Hallegatte et al. (2016c, b, c) examined poverty-specific exposure to floods and drought in 52 countries (Park et al. 2015; Winsemius et al. 2018). The report uses

\section{a. Rural areas}

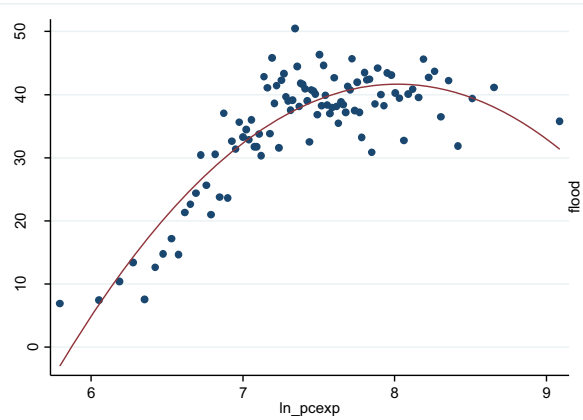

\section{b. Urban areas}

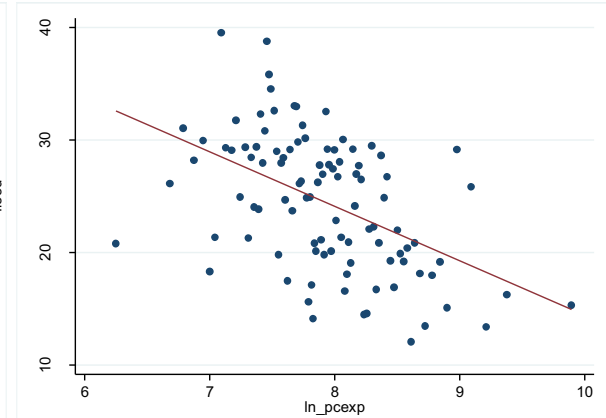

Fig. 5 Flood risk for different consumption percentiles: rural and urban areas of Vietnam, 2014. Source: Narloch and Bangalore 2016. Note: The x-axis in both panels shows the percentiles of logged per capita expenditure among households in 2014. The y-axis in both panels indicates the level of flood exposure. The blue dots show the binned scatterplots - that is, the mean flood exposure for each consumption level. The red line is the line of best fit 
a poverty exposure bias to measure whether poor people are more exposed than nonpoor people to a hazard. For a given area, the poverty exposure bias is the share of poor people exposed to a hazard, divided by the share of the total population exposed, minus 1. A positive bias means poor people are more exposed than average; a negative bias implies poor people are less exposed than average.

For river floods at the country level, we find mixed results as illustrated in panels a, b, and c of Fig. 6. It represents the poverty exposure bias for floods with a 10-year return period (or $10 \%$ annual probability of occurrence). No regional pattern emerges, except for Africa: countries in the southwest exhibit strong overexposure of poor people, as do those in the west

a. Latin America and the Caribbean, national

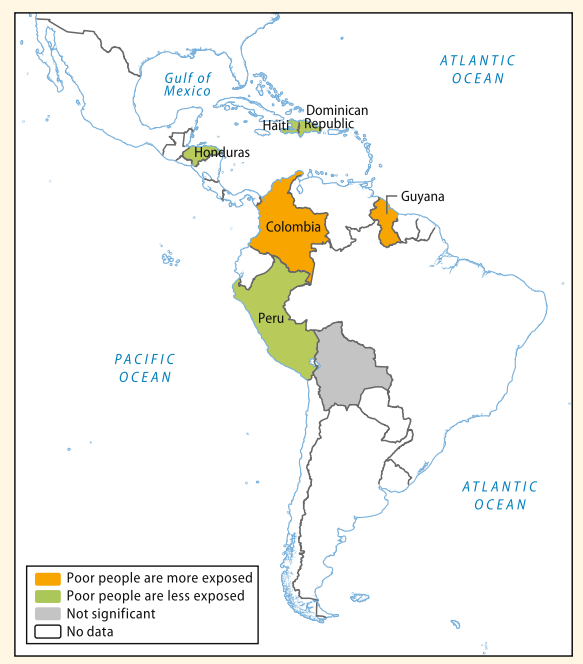

b. Africa and Europe, national

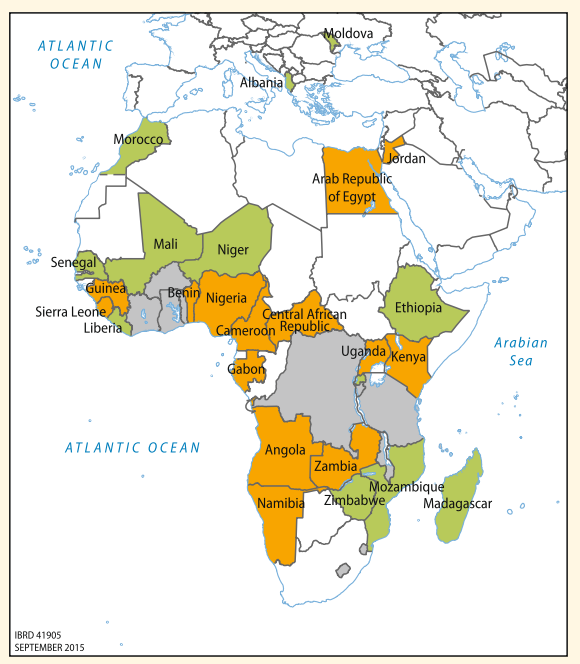

C. Asia, national

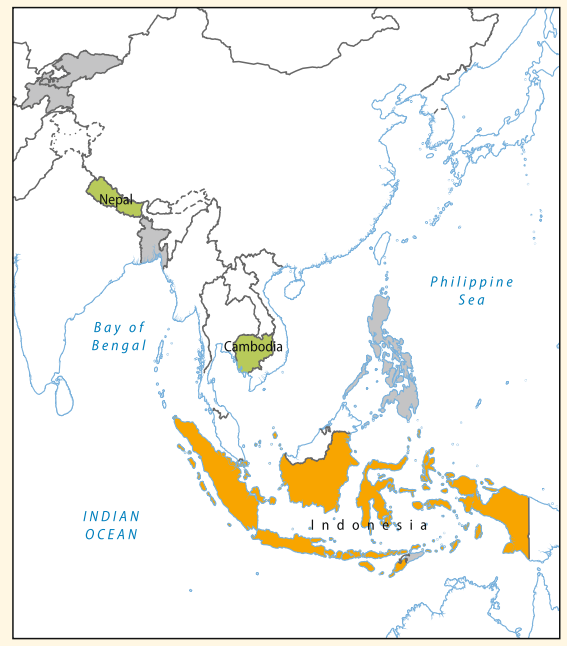

Fig. 6 Poverty exposure to floods, 52 countries: all households (a, b, c); urban households only (d, e, f). Source: Winsemius et al. 2018. Note: Maps are based on Demographic Household Survey 

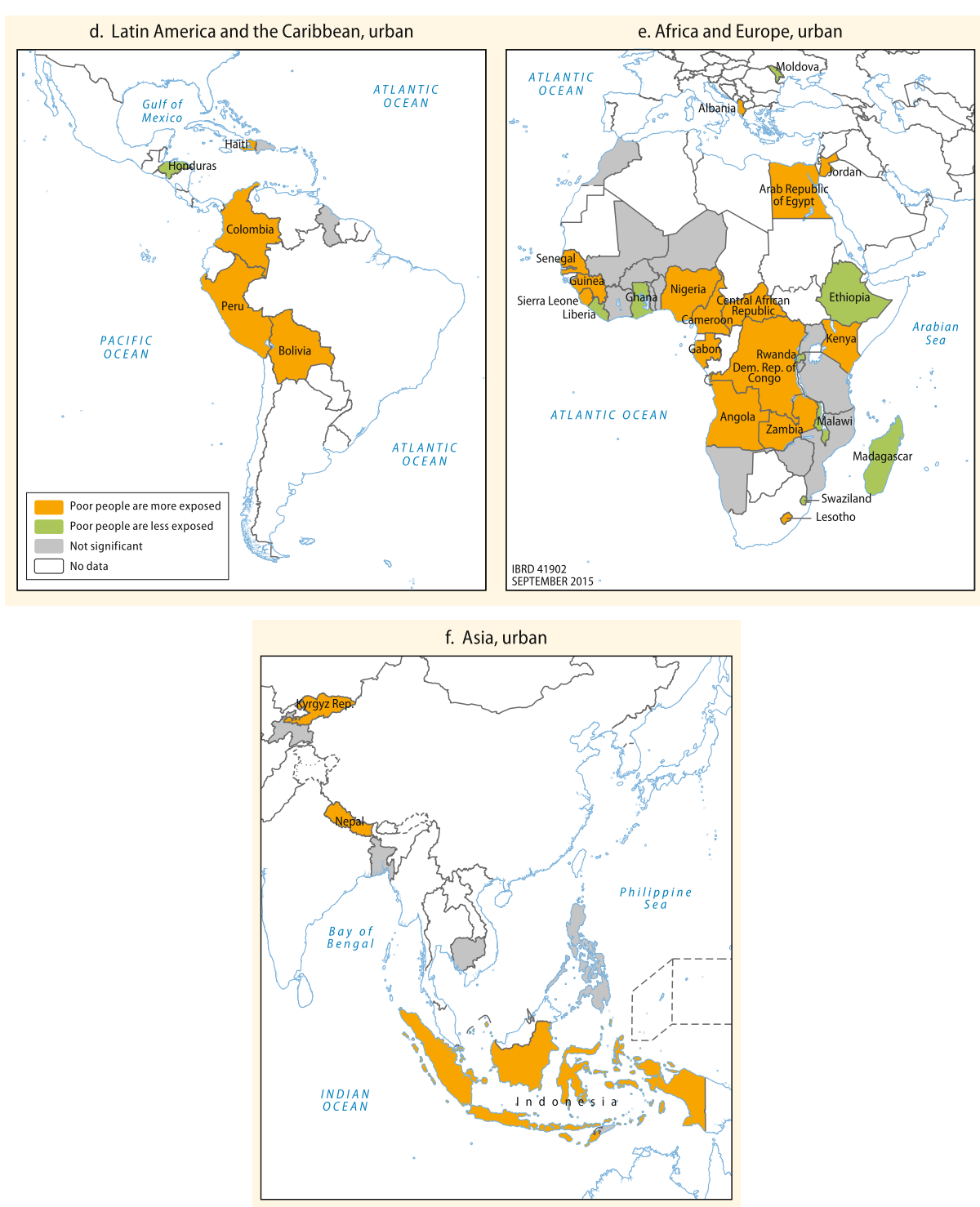

Fig. 6 (continued)

with larger rivers such as Benin, Cameroon, and Nigeria. About $60 \%$ of the population of the analyzed countries live in countries where poor people are more exposed than average to floods.

When we focus only on urban households, the results reveal a clear difference between the exposure of poor and nonpoor people, as can be seen in panels d, e, and f of Fig. 6. In most countries (about $73 \%$ of the analyzed population), poor urban households are more exposed to floods than the average urban population. There is no such pattern for rural households, suggesting that land scarcity is a driver of flood risk in urban areas. 
For drought, the poverty exposure bias is evident: $85 \%$ of the analyzed population lives in countries in which poor people are overexposed to drought. In most Asian and African (except for Niger, Tanzania, Malawi and Namibia) countries, poor households are more exposed to drought. In Latin America, poor people appear underexposed in Bolivia and Peru, but overexposed in Colombia, Guyana, and Honduras.

Finally, people are often more exposed to higher temperatures: 37 out of 52 countries (representing $56 \%$ of the population) exhibit a positive bias. Many of these countries are already hot. Cooler countries exhibit a smaller bias, and in some cool countries a negative bias because in these cool countries the nonpoor tend to settle in areas with higher temperatures, which are climatically more desirable. These results suggest a sorting of the population into desirable and less desirable areas within a country, with wealthier households typically living in desirable areas and poorer households in less desirable ones.

\section{Recurrent Hazards and Hidden Costs}

Large-scale events make the news, but repeated small adverse events such as regular floods often have serious implications for poor people. Although poor and nonpoor people may decide to live in places that are sometimes affected by natural hazards, only poor people live in dwellings which are frequently exposed to natural hazards.

For example, recurrent floods in Mumbai, India, during the monsoon season, have significant impacts on poor people (Patankar 2015). A survey of 200 households has yielded two key insights. First, floods cause problems with transport, drinking water, power supply, and food and fuel availability. It also has economic consequences because affected households lose workdays - on average 2.5 a year because of poor infrastructure (more than $50 \%$ of surveyed people cite the unavailability of transport or flooded roads)-implying a loss of income, productivity, and sometimes jobs. Second, floods cause diarrhea in $40 \%$ of households each year, malaria in $64 \%$, and viral fever in $86 \%$. Health problems are also observed in Metro Manila, the Philippines, because of improper sanitation and lack of potable water and health systems. In this city, only a small fraction $(13 \%)$ of those who were sick were able to obtain free medicine; all others had to pay out of pocket. On average, households spent 1930 pesos on medical care, and some households reported spending more than 10,000 pesos (Porio 2011).

\section{Vulnerability Bias: Do Poor People Lose More when Hit by a Disaster?}

Exposure is only one component of risk; vulnerability is another. Vulnerability is defined here as the fraction of wealth lost by people when they are hit by a shock. Do poor people lose more than the nonpoor as a result of a disaster? To determine the differences in vulnerability, we use thirteen local case studies which have examined exposure to a disaster by poverty status, and five (in Bangladesh, Honduras, and Mumbai) which have examined the losses of the poor and nonpoor separately (calculated as income losses, asset losses, or both). As they have more assets and higher incomes, wealthier people lose more from flood or storm in absolute terms. In relative terms, however, poor people always lose more than the nonpoor from floods and storms (Fig. 7).

In Mumbai, for example, the 2005 floods not only caused direct losses of household assets but also led to lost income and large expenditures on home repairs or reconstruction (Patankar and Patwardhan 2016). According to a survey of 1168 households, the nonpoor had higher 


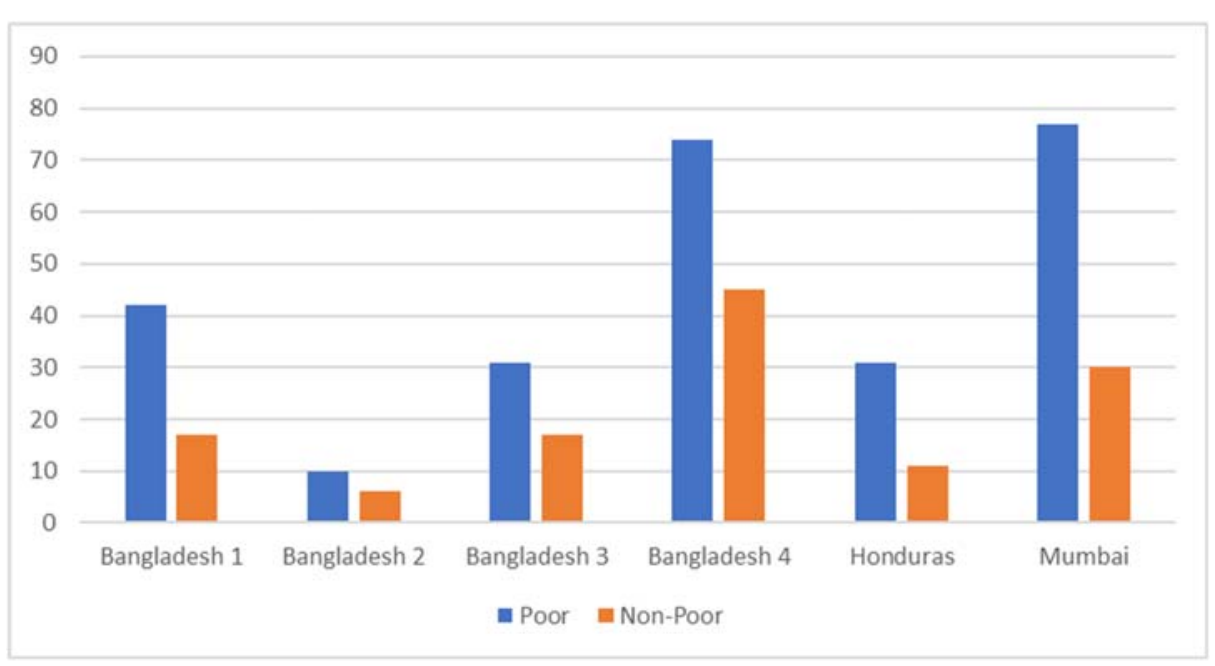

Fig. 7 Percent of assets or income lost due to a disaster, poor and nonpoor: Bangladesh, Honduras, and Mumbai, India. Sources: Bangladesh, 1: del Ninno et al. 2001; Bangladesh, 2: Brouwer et al. 2007; Bangladesh, 3 : Rabbani et al. 2013; Honduras: Carter et al. 2007; Mumbai: Patankar and Patwardhan 2016. Note: Each study uses a different definition of "poor" and "nonpoor" for its sample. The four Bangladesh studies use percentage of income loss as a metric, and the Honduras and Mumbai studies use asset loss

absolute losses, but the poor lost more as a percentage of income across all three loss categories (Table 1). When income, asset, and repairs were combined, the total losses from the event reached $85 \%$ of the average annual income of the poorest people.

Why do poor people lose relatively more? The following sections review the different vulnerabilities that poor people are exposed to.

\section{Asset Vulnerability}

The typical asset portfolio of a poor person and a nonpoor person is very different. Unlike the nonpoor, poor people tend to have less diversified portfolios, and their savings are more vulnerable to natural hazard (investments in their home, livestock) compared with richer individuals (who have intangible savings, such as bank accounts). This factor of vulnerability suggests that financial inclusion, especially targeting poor people through savings and borrowing products designed for their needs, could be a powerful risk reduction strategy (Morduch 1995; Kinnan and Townsend 2012; Demirguc-Kunt et al. 2018; Moore et al. 2019; Erman et al. 2019).

Table 1 Losses from floods by income level: Mumbai, India, 2005

\begin{tabular}{lrlllll}
\hline Average annual income (Rs) & $\mathrm{n}$ & $\begin{array}{l}\text { Total loss } \\
\text { (Rs.) }\end{array}$ & $\begin{array}{l}\text { Income loss } \\
\text { (as \% of yearly income) }\end{array}$ & $\begin{array}{l}\text { Asset loss } \\
\text { (a) }\end{array}$ & Total loss \\
\hline$<0,000$ & 192 & 46,478 & 16 & 29 & 40 & 85 \\
120,000 & 806 & 58,378 & 10 & 20 & 22 & 52 \\
270,000 & 124 & 78,477 & 6 & 13 & 12 & 31 \\
450,000 & 15 & 113,020 & 3 & 7 & 21 & 32 \\
$>540,000$ & 10 & 87,750 & 8 & 4 & 8 & 19 \\
\hline
\end{tabular}

Source: Authors' calculations, based on Patankar and Patwardhan 2016

Rs $=$ rupees 
In addition to the portfolio composition effect, the quality of assets owned by poor people is lower. An example is housing stock. Households living in slums or informal settlements constructed of wood, bamboo, and mud and occupying steep slopes will suffer more damage from a natural disaster than households whose homes are made of stone or brick. In coastal communities in southwest Bangladesh following Cyclone Aila, $76 \%$ of households in kacha houses (traditional homes built of mud and bamboo) reported structural damage-far above the $47 \%$ for those in pucca houses (built of concrete and wood). In terms of economic damage, the average for kacha houses, $\$ 400$, was also well above the $\$ 133$ for pucca ones (Akter and Mallick 2013). In Jamaica, Henry et al. (2019) investigate the impact of tropical storms on household consumption and find that only households that live in buildings with less wind resistant walls are affected.

\section{Agricultural Income and Ecosystems}

Poor people, especially in rural areas without functioning markets, are highly dependent on agricultural income and ecosystems, and they are therefore vulnerable to the impacts of natural disasters on yields and the health and functioning of ecosystems. Large-scale events can wreak havoc on natural capital and threaten these sources of income. This is what happened in 2008 when Cyclone Nargis hit southwest Myanmar. It killed 140,000 people and inflicted damage on embankments and streams, making fields more prone to flooding. Moreover, after Nargis the duration of daily and monthly tides became longer, making fields more saline and prone to pest infestation. As a result, yields fell, as did incomes.

On the other hand, natural capital also often serves as a safety net after a disaster when not depleted (Barbier 2010). In Bangladesh after Cyclone Aila hit in 2009, households living closest to the coast, while more exposed and vulnerable to the storm (and poorer), had more resilient income because the proximity to mangrove reserves offered higher income generation opportunities than those available to inland inhabitants (Akter and Mallick 2013). However, the effects of climate change on these ecosystems may impair their ability to serve as a safety net and to smooth consumption in the face of shocks (Noack et al. 2015).

In developing countries, livelihood diversification is becoming a crucial part of dealing with natural hazards. For example, engaging with tourists can serve as a means of livelihood diversification (Mbaiwa and Sakuze 2009). Crop choice and other forms of agricultural diversification are a form of insurance against various agricultural risks for rural households, which have been used in Ethiopia by risk-averse farmers (Mesfin et al. 2011).

This said, the better-off have better opportunities to diversify their livelihood. For example, their greater access to credit and financial capital, or advantages in the labor market provide them with more diversification opportunities (Barrett et al. 2001).

\section{Consumption Patterns and Food Security}

Because of the lack of access to markets, isolated communities in rural areas are more vulnerable to the food security consequences of a natural disaster. Indeed, if local production is lost to a drought or a flood, they cannot rely on production from other areas. Safir et al. (2013) found a 4\% decrease in food consumption in areas of the Philippines with low precipitation, but this effect disappears in areas close to highways.

Even in well-connected areas, natural disasters can result in food price spikes because of supply shocks. Disasters can destroy crops and seed reserves, destroying in turn productive 
assets in agricultural communities and sparking food price shocks, as occurred after the unprecedented 2010 floods in Pakistan (Cheema et al. 2015). The floods destroyed 2.1 million hectares of agricultural land, decimating production and sending the price of wheat up to more than $50 \%$ above the preflood level.

However, poor people are more vulnerable to increases in food prices: in developing countries, that spend on average between 40 and $60 \%$ of their household budget on food - far more than the $25 \%$ spent by the nonpoor (Hallegatte et al. 2015). However, effects are often complex, and the sometimes disasters affect the food basket composition, more than the total calories amount. For instance, McCarthy et al. (2018) analyze the impacts of the floods that occurred during the 2014/15 growing season in Malawi, and find that while maize yields were lower for all households, drops in food consumption expenditures were less dramatic, and calories per capita were higher. But dietary diversity was significantly lower, suggesting that households adjust their consumption basket to maintain total intake at a lower cost (but at the expense of micronutrients).

More generally, poor people are less able to cope with income losses by adjusting their consumption basket. They cannot cut back on luxury consumption or delay consumption the way wealthier households can. In many countries they are close to the subsistence level, which means that reducing consumption can have immediate negative impacts on health (if food intake is reduced or medical care becomes unaffordable), education (if children are taken out of school), or economic prospects (if essential assets have to be sold) (Karim and Noy 2016). These consumption cuts have a large impact on immediate well-being, but can also affect human capital through health or education, creating long-term consequences on income and prospects (see below).

\section{Mitigation Mechanisms: Higher Productivity of Capital and Transfers}

All this said, poor people do have sources of resilience. For one thing, as discussed by Hallegatte and Vogt-Schilb (2019), physical capital is scarce in many developing countries, and production is more labor-intensive. The productivity of capital thus tends to be higher in low-income countries. Consequently, with less physical capital to damage, the asset losses from natural disasters are smaller when compared with production, and a smaller share of consumption needs to be redirected toward reconstruction. This reduces the impact on well-being and the duration of the reconstruction phase.

Another source of the resilience of poor people is the transfers they receive from government or family. In most countries, a large share of the income of poor people is composed of transfers, and especially from social protection (cash transfers, work programs, subsidies, contributory pensions and health insurance, and unemployment compensation). Thus, if their labor income is reduced or interrupted by a disaster, the relative effect on total income is smaller, assuming that transfers are unchanged. This pattern is not observed, however, in lowincome countries: below $\$ 5000$ in GDP per capita (PPP-adjusted), the difference in the income structure of the poor and nonpoor is small, and the share of income from transfers in these countries is very low, usually less than $15 \%$. Therefore, the entire population of these countries is dependent on labor income, which is vulnerable to natural disasters.

\section{Socioeconomic Resilience: Are Poor People less Able to Cope with and Recover from Disasters?}

With less resources, poor people struggle more to cope with and recover from disasters. Poor people also tend to be more alone in the struggle to cope and recover: they receive less support 
than nonpoor people from financial instruments, social protection schemes, and private remittances. For example, in response to the flooding and landslides in communities in Nepal in 2011 , only $6 \%$ of the very poor sought government support, compared with almost $90 \%$ of the well-off (Gentle et al. 2014).

As a result, there is evidence that people at lower income level have more difficult to recover from natural disasters. For instance, in Dar es Salaam, Tanzania, Erman et al. (2019) find that the households who have recovered from the previous floods, at the time of the survey in 2018, have on average a higher income (Fig. 8). The same is found for Accra, Ghana, even though in this case, the correlation between income and ability to recover disappears when other characteristics are controlled for (e.g., source of income, ability to access emergency support from friends and family) (Erman et al. 2020). The conclusion is that growing income and boosting resilience are not the same thing, but that the lower "socioeconomic resilience" of poor people is one major factor behind the larger effect that disasters have on their well-being.

\section{Insurance and Post-Disaster Support}

Domestic insurance markets have also proven to be an effective channel for developing the resilience of disaster-exposed households and businesses. The Turkish Catastrophe Insurance Pool (TCIP) and the Mongolian Livestock Insurance Pool are good examples of public-private partnerships. In both of these cases, the domestic insurance market provides the mechanism through which governments are able to reach households and businesses with insurance products to realize their policy goals of expanding the financial resilience of the population to disasters. Both partnerships have substantially increased insurance penetration at the local level.

Where insurance is not compulsory, the pick-up rates remain low. Even in Japan, a highincome country in which insurance against earthquakes is subsidized, less than $30 \%$ of homeowners are covered (Insurance Bureau of Canada 2015). And in the United States or Italy, where earthquake insurance is not subsidized, penetration rates are $11 \%$ and $3 \%$ respectively. A successful scheme such as the Mongolian Livestock Insurance Pool, which

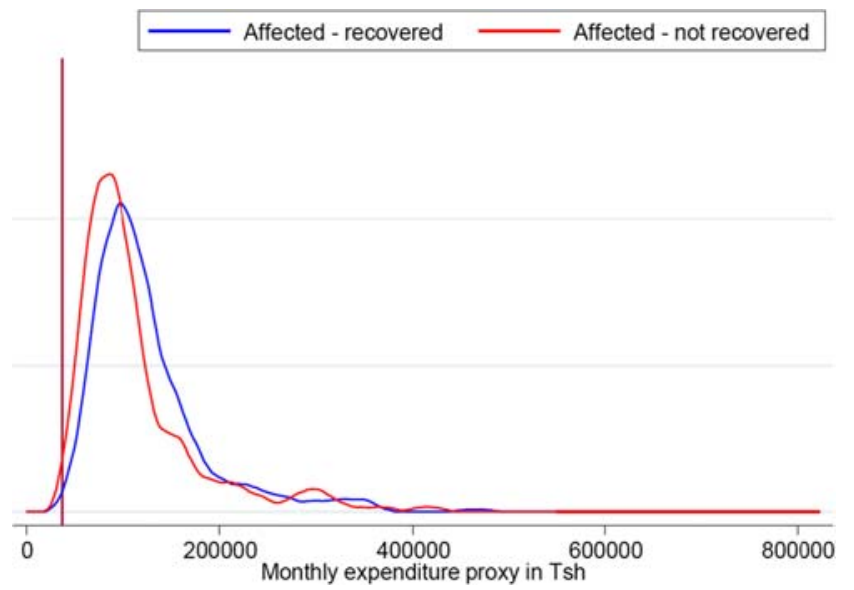

Fig. 8 Distribution of the expenditure proxy and comparison between households that recovered and did not recover from flood. Source: Erman et al. (2019) 
covers more than 10,000 herders and was initiated in 2005 , still has a relatively low pick-up rate (less than $15 \%$ of the herders in the covered areas).

In developing countries, poor people usually have no access to disaster insurance due to affordability issues, large transaction costs for small portfolios, and weak institutions and lack of trust (Kunreuther et al. 2013). And even in rich countries where disaster insurance is provided through public-private partnership, the effect of insurance has been found to be regressive (Owen and Noy 2019).

Even when poor households receive support after a disaster, the amounts received are often too small to enable better coping strategies. In Bangladesh following the 1998 Great Flood, the targeting was relatively good: $66 \%$ of households in the bottom quintile received transfers, compared with $33 \%$ in the top quintile (del Ninno et al. 2001). However, the transfer amounts were small (only $4 \%$ of the total household monthly expenditure for poor households), and poor households affected by the flood borrowed six to eight times more than this amount of the transfer.

Post disaster support often fails to provide the poorest with enough resources because of their lack of voice and influence. When poor people are excluded from governance and have no say in the decision-making process, support is unlikely to be provided in a timely and adequate manner. In particular, different categories of the population compete for help after a disaster, and those with better connections are likely to get more, or faster, support. In two case studies on Thailand, it was found that the majority of government support after a flood benefited the well-off, with 500 baht per capita (about \$14) going to the richest quartile, compared with 200 baht per capita for the poorest quartile (Noy and Patel 2014).

\section{Safety Net Programs}

After a shock, when income and wealth are reduced and people's health is affected, broad safety net programs may automatically scale up if they are designed to respond to changes in household situations. In the United States, postdisaster support through nondisaster programs is more than five times larger than the dedicated transfers that follow federal disaster declarations. Nondisaster transfers per capita in affected counties increase by about $\$ 1000$ (compared with $\$ 150$ for dedicated postdisaster support). Most of these transfers are from Medicare (especially disability) and unemployment insurance (Deryugina 2016). Strong social programs thus increase people's resilience even in the absence of explicit disaster-related triggers.

But there are obvious limits to what nondisaster programs can achieve in the aftermath of a disaster. First, budgetary constraints or the design of the programs can make it impossible for transfers to increase enough or to increase fast enough. This is particularly true in developing countries with liquidity constraints, where the ability to scale up is limited in the absence of a dedicated financial mechanism.

Second, the coverage of social protection programs is limited in developing countries, and these programs are therefore not always able to support the affected population. Although conditional and unconditional cash transfers specifically target poor households and are increasingly associated with good coverage among households in the bottom quintile, the two other types of transfers - social insurance and labor market policies - reach poor and nonpoor households in about the same proportion. This does not necessarily mean that those schemes are poorly designed; some programs such as contributory pensions are designed for those who can afford to contribute. 
Moreover, poor people are often excluded from programs that should benefit them. Aldrich (2010) shows that access to post-disaster assistance in India (after the 2004 tsunami) was biased away from the most disadvantaged and poorest castes. In Aldrich (2012), the same author argues that generally the poor have less social capital, and therefore are disadvantaged pre- and post-disaster in multiple dimensions. For example, some programs are tied to formal employment, whereas most poor people work in the informal economy. Also, poor people in remote rural areas can be difficult to reach. However, the conditional and unconditional cash transfer programs that have revolutionized social protection over the last decade are easier to deploy in rural areas than in urban areas because of the challenge of targeting the poor in cities where they often live next door to the wealthier (Gentilini 2015).

Finally, targeting methods used by social assistance programs are often based on data that are costly and hard to collect. It makes it difficult for these programs to adjust quickly to the changing conditions of households, as would be needed to prevent the negative coping behaviors in the aftermath of a disaster such as reduced food intake (Bastagli 2014; Gentilini 2015; Kuriakose et al. 2013).

\section{Domestic and Global Remittances}

Remittances - that is, the private transfer of money by foreign workers to individuals in their home country — were estimated at $\$ 584$ billion worldwide in 2014 . They are a vital resource for developing countries and significantly exceed official development assistance. After natural, economic, financial, and political shocks, these flows have been found to either remain stable or increase (Clarke and Wallsten 2004; Fagen 2006; Mohapatra et al. 2009; World Bank 2015). Thus, they can help smooth consumption and finance recovery and reconstruction. In the Philippines, it was estimated that remittances compensated for nearly 65\% of lost income after rainfall shocks in 1997 (Yang and Choi 2007). In Indonesia, households that received remittances in the Aceh region recovered faster from the 2004 tsunami, despite disruptions in financial services and informal transfer channels (Wu 2006). However, international and domestic remittances tend to benefit the better-off within a country (Fig. 9). For example, Henry et al. (2019) find that in Jamaica, the households that are able to partially buffer the effects of tropical storms on consumption (through savings and remittances) are the ones who live in buildings with more wind-resistant walls.

\section{Conflict-Prone Areas}

A weakened capacity to respond to a natural hazard, at whatever the level of government, is one reason natural disasters have worse impacts in an area that is already riddled by conflict. ${ }^{1}$ Generally, the vulnerability to climate shocks is highest in more fragile and conflict-affected areas (UNISDR 2009). And because many poor people live in such fragile areas, they usually receive less support when they are hit by a hazard. Indeed, countries in the throes of a violent conflict and governance issues are less likely to successfully support local communities in their struggles to cope with the aftermath of natural disasters (IPCC 2012). For example, in Somalia, the government does not have full control of its territory, and so it cannot respond successfully to natural disasters (Ferris 2010). This determinant of the vulnerability of the poor will become increasingly important: by 2030, almost half of the world's poor is expected to live in countries affected by fragility, conflict, and violence. 


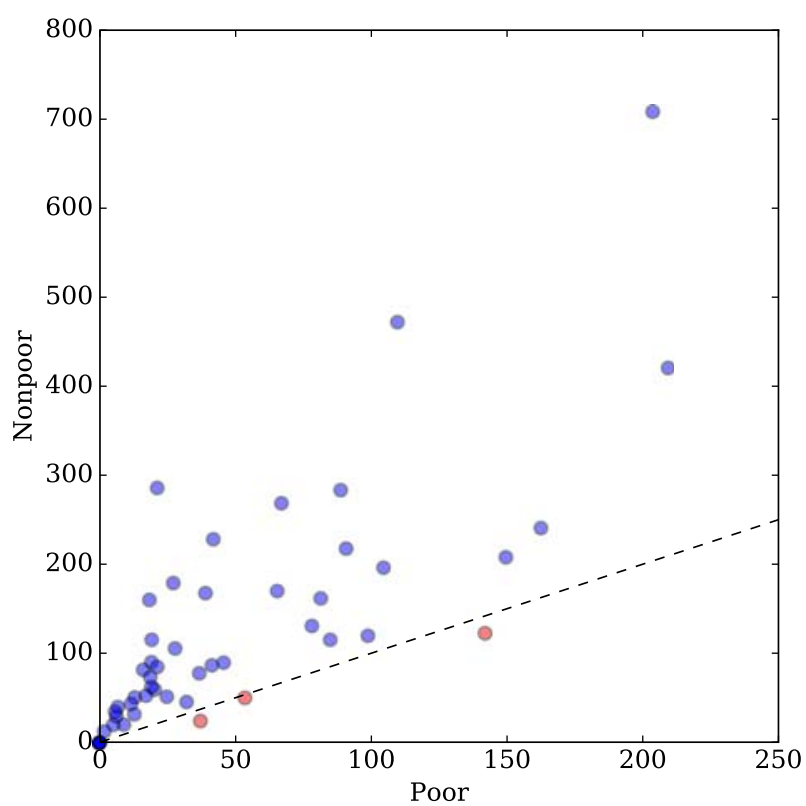

Fig. 9 Remittance transfers, poor and nonpoor. Source: ASPIRE database, World Bank, http://datatopics. worldbank.org/aspire/. Note: $\mathrm{PPP}=$ purchasing power parity. Each dot represents a country for which adequate data exist

In summary, poverty is a major driver of people's vulnerability to natural hazards and natural disasters. An important implication is that poverty reduction and developmentprovided they do not create excessive new risk - make people less vulnerable and contribute to disaster risk management and reduction. Policies that contribute to reducing poverty can therefore be considered a tool in the disaster risk management toolbox.

\section{Vicious Circles: Why Do Natural Disasters Keep People in Poverty?}

Poverty reduction is not a one-way street out of poverty, and natural disasters are one of the reasons why. Surveys reveal that natural disasters are partly responsible for the flow of households into poverty. In Senegal, a household affected by a natural disaster was $25 \%$ more likely to have fallen in poverty over the 2006-2011 period (Dang et al. 2014). In India, among the $12 \%$ of households in 36 Andhra Pradesh communities that fell into poverty over a 25-year period, 44\% cited "drought, irrigation failure, or crop disease" as one of the reasons for their income losses (Krishna 2006).

Many studies have demonstrated that after a disaster (floods, hurricane, and storm), poverty tend to increase (Karim and Noy 2016). For instance, in Bolivia, the incidence of poverty climbed by $12 \%$ in Trinidad City after the 2006 floods, a fivefold increase compared with the national average (Perez-De-Rada and Paz 2008). In the Philippines, the El Niño season that began in September 1997 increased the poverty headcount by 4-5\% (Datt and Hoogeveen 2003). In Mozambique, (Baez et al. 2019) find that experiencing a cyclone, flood, or drought leads to a drop of up to $25-30 \%$ in per capita food consumption and around 0.4 fewer meals 
per day per person. Poverty increased by 12 and 17.5 percentage points in two of the three events analyzed.

Beyond the immediate impact after a disaster, evidence suggests that natural disasters increase poverty over the medium and long term. Glave et al. (2008) studied exposure to disasters and poverty from 2003 to 2008 at the provincial level in Peru. They found that one extra disaster per year increased poverty rates by 16-23\%. In Ecuador, Calero et al. (2008) found that from 1970 to 2007 exposure to drought increased the incidence of poverty by $2 \%$ on average. And in Asia, Akter and Mallick (2013) surveyed households in coastal communities affected by Cyclone Aila in 2010 in the southwest of Bangladesh. Unemployment skyrocketed, from $11 \%$ in 2009 to $60 \%$ in 2010, and the poverty headcount rate increased from $41 \%$ before the storm to $63 \%$ afterward.

However, the impact of natural disasters on poverty is not homogeneous; it depends on local capacity. For instance, in Burkina Faso, Reardon and Taylor (1996) found that drought conditions in the 1980s increased poverty levels by $17 \%$ in the Sahelian zone (poorest climate, least household diversification) and by $3 \%$ in the Sudanian zone, but not in the Guinean zone (best climate, most household diversification).

This large and growing body of empirical evidence suggests that household well-being and poverty status are largely susceptible to natural disasters, at least in the short term. But what are the drivers of these impacts?

\section{Disasters Impact on Economic Growth}

Aggregate economic growth is the main driver of poverty reduction over time (Dollar et al. 2013; Dollar and Kraay 2002), and so any impact of disasters on economic growth has direct implications for poverty.

Researchers agree that disasters, especially high-intensity ones, have negative shortterm impacts on economic growth (Cavallo and Noy 2009). For example, Felbermayr and Gröschl (2014) find that disasters in the top decile of magnitude result on average in a $3 \%$ reduction in GDP growth. The loss is only $1.5 \%$ for disasters in the top $15 \%$ of magnitude and $0.8 \%$ for disasters in the top $20 \%$. For smaller disasters, they detect no impact. Impacts are also visible at the subnational level. Strobl (2010) has investigated the impact of hurricane landfall on county-level economic growth in the United States. Growth in a county struck by at least one hurricane over a year is reduced on average by 0.79 percentage points.

There is little doubt, then, that such short reductions in economic activity, GDP, or economic growth have a direct impact on short-term poverty and poverty reduction. By contrast, the long-term impacts of natural disasters on growth remain less clear. Although early studies, notably by Albala-Bertrand (1993) and Skidmore and Toya (2002), suggested natural disasters have a positive influence on long-term economic growth, a few recent studies find negative impacts on long-term economic growth.

It is the case of Peter, Dahlen, and Saxena' study (2012). Using a data set of natural disasters from 1960 to 2011, they find that a typical natural disaster causes a drop in long-term economic growth of $0.6-1.0 \%$ and results in a permanent output loss of two to three times this magnitude, with higher estimates for larger natural disasters. A recent study by Best and Burke (2019) investigated the impact of the 2010 earthquake on GDP in Haiti. The authors found that even up to 6 years after the event (the 6 years cut-off was limited by the end of their sample period) losses still amounted to an average of $12 \%$ of Haiti's annual GDP. 
Although these studies find long-term impacts, most existing studies find a return to normal economic conditions after a few years. In a recent meta-analysis using more than 750 estimates, Klomp and Valckx (2014) confirm that natural disasters appear to have a negative effect on growth, particularly in developing countries. However, the impact is in the short term; long-term GDP per capita returns to its original growth path. Using the same counterfactual methodology as Coffman and Noy (2012) and comparing across countries and decades, Cavallo et al. (2013) find that natural disasters do not have any significant effect on subsequent long-term economic growth. The largest disasters (such as those in the 99th percentile) have some long-term impacts on growth, but this effect disappears entirely when controlled for political change: the long-term impact occurs only when the disaster is followed by political instability. This result suggests that the secondary impacts of natural disasters through political instability and conflicts could play a major role in determining their longterm effects. In a recent review, Noy and duPont IV, (2018) argue that since economies are constantly changing, one cannot compare the economy long after the disaster to what it was before. The method used by researchers thus have a significant impact on results, and it is hard to conclude on the presence or absence of long-term impact.

\section{Disasters Impact on Conflict}

In 2013 the Overseas Development Institute (ODI) issued a special report summarizing the literature on the natural disaster and conflict nexus (Harris et al. 2013). The report concluded that more often disasters exacerbate existing conflicts because they add to existing grievances, reduce opportunities in the immediate aftermath, and lead to a power vacuum, which may be filled by criminal groups.

The outcome depends on how the authorities react. A natural disaster may give way to grievances that could translate into conflict if they are not addressed properly. An example is the 1970 typhoon in East Pakistan. The failed response of the central government in West Pakistan contributed to the civil war and the struggle for independence, which eventually led to the creation of Bangladesh. In this case, popular discontent with the disaster response was the reason the government was overthrown (Bhavani 2006).

The 2004 Indian Ocean tsunami, one of the deadliest natural disasters ever recorded, provides insights into the impacts of a disaster on conflict. The tsunami struck 14 countries. The two worst affected, Indonesia and Sri Lanka, were both in a state of civil war, but had very different responses to the tsunami.

In Aceh, a territory in Indonesia, the natural disaster brought peace to a region that had been in the throes of a civil war for nearly 30 years. The tsunami crucially contributed to the cessation of violence between the Indonesian army and the Acehnese rebels and to the signing of a peace treaty. The floods made way for a massive humanitarian response and unprecedented cooperation between the central government and the rebels as they sought a unified response to the disaster. Jakarta first responded by lifting military emergency law, which paved the way for reconstruction.

By contrast, in Sri Lanka, the tsunami may have had the opposite effect. The tsunami's role in the ongoing conflict in Sri Lanka is less clear than the one in Aceh. However, the floods appear to have stoked the flames of war and rekindled violence and armed conflict (Kuhn 2009). 


\section{Direct Disasters Impact in the Absence of Visible Impacts on GDP}

The impact of natural disasters on poverty is not necessarily due to their effect on economic growth. Disasters may affect poverty directly in many ways. Even when losses from disasters are small on average, some victims may lose everything during an event, including their health and, in the case of children, their chances of escaping poverty through education.

\section{Disproportionate Long-Term Impacts}

Because poor people suffer disproportionately from natural disasters, these events increase inequality, making the impacts of disasters highly heterogeneous. The average losses may underestimate the effects of large losses on some individuals, especially those who are close to the subsistence level.

Large losses by some households can have long-term consequences. After Ethiopia's 198485 famine, it took a decade on average for asset-poor households to bring livestock holdings back to prefamine levels (Dercon 2004). One explanation offered by Carter and Barrett (2006) is that if household assets go below a certain critical value - the Micawber threshold - it becomes difficult or almost impossible to rebuild the asset stock, and people may end up locked in poverty traps.

\section{Irreversible Impacts on Health and Education}

After intense shocks, poor households may be forced to make choices with detrimental longterm effects, such as withdrawing a child from school or reducing health care expenses. For the people experiencing large losses, the possible long-term effects, such as a reduction in food intake, health effects and disability, and exclusion from job markets, can push households into poverty traps. In addition, there is evidence that children in utero and young children are the most vulnerable to natural disasters and suffer the most long-lasting negative effects, contributing to the intergenerational transmission of poverty (Caruso 2017).

Impacts on education are prevalent. In Africa, enrollment rates have declined $20 \%$ in regions affected by drought (Jensen 2000); drought-affected households have delayed starting children in school by 3.7 months on average, and 0.4 fewer grades are completed (Alderman et al. 2006). Such findings are not restricted to Africa; similar postdisaster impacts on health and education have been found in Asia, Latin America, and elsewhere (Baez et al. 2010; Maccini and Yang 2009) (Baez et al. 2019; Rush 2018).

Evidence also suggests that disasters have acute impacts on health. Sometimes, the effect is direct; for instance when floods bring diseases (Yonson 2018; Erman et al. 2019; Noji 2000; Sur et al. 2000). Sometimes, the impact goes through lower postdisaster consumption, especially after a drought. In Sub-Saharan Africa, asset-poor households respond to weather shocks by reducing the quality of the nutrition provided to their children (Alderman et al. 2006; Dercon and Porter 2014; Hoddinott 2006; Yamano et al. 2005), a behavior which has short- and long-term impacts, particularly for children younger than 2. For example, within this group, the stature of children in these households was permanently lowered by $2-3 \mathrm{~cm}$ (Alderman et al. 2006; Dercon and Porter 2014).

In Central America, major disasters have also reduced investments in human capital. In Guatemala, Storm Stan increased the probability of child labor by $7.3 \%$ in departments hit by the storm (Bustelo 2011). Natural disasters also increase the multidimensional poverty index 
through a deterioration of "education conditions" and "child and youth conditions," as demonstrated by Sanchez and Calderon (2014) for Colombia from 1976 to 2005.

\section{Reduced Incentives to Invest}

The losses the poor suffer are not the only way in which disasters and natural risks contribute to ongoing poverty. When people do not have the proper tools to manage natural risk, they tend to spread risk over a large array of lower-risk activities and to reduce their investments, thereby reducing in turn returns to assets and income (Hallegatte et al. 2016b; ODI and GFDRR 2015; World Bank 2013). For example, smallholders plant low-return, low-risk crops and limit their investment in fertilizers (Cole et al. 2013). Ex ante reductions in investments thus account for two-thirds of the difference (the rest stems from the actual destruction of capital because of shocks).

Disaster risk reduction can thus generate growth and benefits, beyond avoided losses, by promoting more investment. The Triple Dividend report refers to this benefit as the "second dividend of disaster risk reduction" (ODI and GFDRR 2015). (The first dividend is that disaster losses can be avoided, and the third dividend refers to co-benefits such as when a water retention area can also be used as a recreation park or a dike is combined with a road.)

Existence of the second dividend is supported by empirical evidence. In Ethiopia, the R4 Rural Resilience Initiative (previously HARITA) program is providing risk management support, including weather-indexed insurance, to small-scale and subsistence farmers. An evaluation of the program has found that insurance is enabling farmers to increase their savings, which can act as an important reserve in the case of floods or drought. Moreover, insured farmers increase their investments in productive assets - in particular, oxen, fertilizer, improved seeds, and compost — thereby improving their overall productivity (Madajewicz et al. 2013).

The second dividend also has implications for future disasters: as countries become richer and better able to afford better protection, they will invest in measures that would prevent the most frequent events (drainage systems, irrigation...). As a result, they will see a reduction in the frequency of disasters because only higher-intensity hazards will lead to losses. Reducing the level of risk will also attract additional investment and assets in at-risk areas. However, even though these additional investments are positive and desirable — on average, they increase well-being - they also increase the consequences of a protection failure (or of an exceptional event that exceeds the protection design). Thus countries will experience, and have to be prepared for, rarer but larger disasters (Hallegatte 2017).

\section{How Many People Fall into Poverty every Year Due to Disasters?}

Another metric can illustrate the impact of natural disasters: the number of people who are falling into poverty every year due to natural disasters. In Hallegatte et al. (2016a, b, c), it is estimated that if all disasters could be prevented next year, the number of people in extreme poverty would be immediately reduced by around 26 million $(7$ million if all the most optimistic assumptions are combined, and 77 million if we retain only the most pessimistic assumptions). In the Philippines only, a more precise analysis suggests that almost half a million Filipinos per year face transient consumption poverty due to natural disasters (Walsh and Hallegatte 2020).

As shown in Fig. 10, floods and droughts are responsible for most of the impact on poverty, because of the low-intensity high-frequency events, showing the importance of considering the 

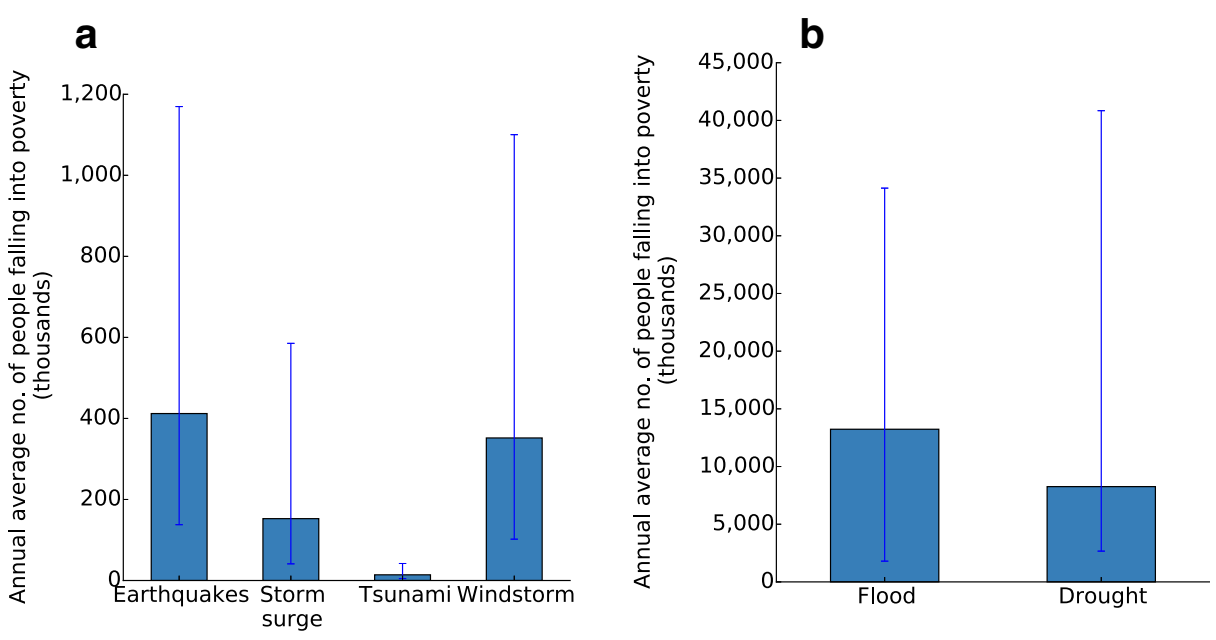

Fig. 10 Simulated impacts of natural disasters on poverty headcount in 2007, 89 countries. a Earthquake, storm surge, tsunami, and windstorm b Flood and drought. Source: Rozenberg and Hallegatte 2017. Note: These numbers are likely to be an underestimation of the current effects of natural disasters on the poverty headcount, because (1) they do not include frequent events (those that happen more than once every 5 years); (2) data for all hazard types are not available in all countries; and (3) some mechanisms and the dynamics of poverty reduction have not been taken into account

effects of recurrent natural shocks that may not be very visible (and may not even be recorded in the media and usual databases) but have nevertheless a large impact on people well-being and long-term prospects (Erman et al. 2019, 2020). Because they are less frequent, earthquakes and tsunamis have a lower average impact on poverty, but it is important to note that these events can have disastrous consequences, and a single earthquake or tsunamis can push millions in poverty at once.

\section{Conclusion}

This paper summarizes the reasons why poor people are expected to be disproportionally affected by natural disasters and highlights the importance of their lower ability to cope with and recover from losses. However, it is critical to note that this specific vulnerability cannot be identified if disaster impacts are measured using the traditional metric, i.e. the repair or replacement value of the assets that have been damaged or destroyed by the disaster. This is the main rationale for the introduction of the concepts of socio-economic resilience and wellbeing losses in Hallegatte et al. (2016a, b, c) or Walsh and Hallegatte (2020): the traditional metrics used to measure the severity of disasters is misleading because it underestimates the impacts of the poorest who have few assets to lose.

The literature review in this paper highlights the importance of natural shocks for the wellbeing and the future of poor people. The papers cited support the idea that disaster risk management can be considered as poverty reduction. In parallel, the fact that poverty is so often one driver of the vulnerability to natural hazards suggests that (well designed) poverty reduction can be considered as disaster risk management. Taken together, these findings highlight the strong synergy between poverty reduction and resilience building and the benefits from an integrated and consistent strategy to both reduce risk and poverty. 
The opinions expressed in this article are those of the authors and do not necessarily reflect the views of the World Bank Group, its Board of Directors, or the countries they represent.

Open Access This article is licensed under the terms of the Creative Commons Attribution-NonCommercialNoDerivatives 3.0 IGO License, which permits any non-commercial use, sharing, distribution and reproduction in any medium or format, as long as you give appropriate credit to the World Bank Group and provide a link to the Creative Commons licence. You do not have permission under this licence to share adapted material derived from this article or parts of it.

The use of the World Bank Group's name, and the use of the World Bank Group's logo, shall be subject to a separate written licence agreement between the World Bank Group and the user and is not authorized as part of this CC-IGO licence. Note that the link provided below includes additional terms and conditions of the licence. The images or other third party material in this article are included in the article's Creative Commons licence, unless indicated otherwise in a credit line to the material. If material is not included in the article's Creative Commons licence and your intended use is not permitted by statutory regulation or exceeds the permitted use, you will need to obtain permission directly from the copyright holder.

To view a copy of this licence, visit http://creativecommons.org/licenses/by-nc-nd/3.0/igo/.

\section{References}

Akter S, Mallick B (2013) The poverty-vulnerability-resilience Nexus: evidence from Bangladesh. Ecol Econ 96:114-124. https://doi.org/10.1016/j.ecolecon.2013.10.008

Albala-Bertrand JM (1993) Political economy of large natural disasters: with special reference to developing countries. Clarendon Press and Oxford University Press, New York and Oxford

Alderman H, Hoddinott J, Kinsey B (2006) Long term consequences of early childhood malnutrition. Oxf Econ Pap 58:450-474. https://doi.org/10.1093/oep/gp1008

Aldrich DP (2010) Separate and unequal: post-tsunami aid distribution in southern India. Soc Sci Q 91(5):13691389

Aldrich D (2012) Building resilience. University of Chicago Press, Chicago

Baez J, de la Fuente A, Santos IV (2010) Do natural disasters affect human capital? An assessment based on existing empirical evidence. Discussion paper no. 5164. IZA, Bonn

Baez JE, Caruso G, Niu C (2019) Extreme weather and poverty risk: evidence from multiple shocks in Mozambique. Economics of Disasters and Climate Change. https://doi.org/10.1007/s41885-019-00049-9

Baker J, Basu R, Cropper M, Lall SV, Takeuch A (2005) Urban poverty and transport: the case of Mumbai. Policy research working paper 3693. World Bank, Washington, DC

Bangalore M, Smith A, Veldkamp T (2019) Exposure to floods, Climate Change, and poverty in Vietnam. Economics of Disasters and Climate Change 3(1):79-99. https://doi.org/10.1007/s41885-018-0035-4

Barbier EB (2010) Poverty, development, and environment. Environ Dev Econ 15:635-660. https://doi. org/10.1017/S1355770X1000032X

Barrett CB, Reardon T, Webb P (2001) Nonfarm income diversification and household livelihood strategies in rural Africa: concepts, dynamics, and policy implications. Food Policy 26:315-331

Bastagli F (2014) Responding to a crisis: the design and delivery of social protection. Overseas Development Institute, London

Best R, Burke PJ (2019) Macroeconomic impacts of the 2010 earthquake in Haiti. Empir Econ 56:1647. https://doi.org/10.1007/s00181-017-1405-4

Bhavani R (2006) Natural disaster conflicts. Manuscript. Harvard University, Cambridge

Brouwer R, Akter S, Brander L, Haque E (2007) Socioeconomic vulnerability and adaptation to environmental risk: a case study of climate change and flooding in Bangladesh. Risk Anal 27:313-326

Bustelo M (2011) Bearing the burden of natural disasters: child labor and schooling in the aftermath of the tropical storm Stan in Guatemala. University of Illinois at Urbana-Champaign

Calero C, Maldonado R, Molina A (2008) Relación entre eventos climáticos y geológicos externos y pobreza. Document prepared for ISDR/RBLAC Research Project on Disaster Risk and Poverty

Carter MR, Barrett CB (2006) The economics of poverty traps and persistent poverty: an asset-based approach. J Dev Stud 42:178-199

Carter MR, Little PD, Mogues T, Negatu W (2007) Poverty traps and natural disasters in Ethiopia and Honduras. World Dev 35:835-856. https://doi.org/10.1016/j.worlddev.2006.09.010

Caruso G (2017) The legacy of natural disasters: the intergenerational impact of 100 years of disasters in Latin America. J Dev Econ 127:209-233 
Cavallo EA, Noy I (2009) The economics of natural disasters: a survey. SSRN Electron J. https://doi.org/10.2139 /ssrn.1817217

Cavallo E, Galiani S, Noy I, Pantano J (2013) Catastrophic natural disasters and economic growth. Rev Econ Stat 95(5):1549-1561

Cheema I, Hunt S, Jakobsen M, Marzi M, O’Leary S, Pellerano L (2015) Citizen's damage compensation Programme: impact evaluation report. Oxford Policy Management, Oxford, U.K.

Clarke G, Wallsten S (2004) Do remittances protect households in developing countries against shocks? Evidence from a natural disaster in Jamaica. World Bank, Washington, DC

Coffman M, Noy I (2012) Hurricane Iniki: measuring the long-term economic impact of a natural disaster using synthetic control. Environ Dev Econ 17:187-205. https://doi.org/10.1017/S1355770X11000350

Cole S, Gine X, Tobacman J, Topalova P, Townsend R, Vickery J (2013) Barriers to household risk management: evidence from India. Am Econ J Appl Econ 5:104-135. https://doi.org/10.1257/app.5.1.104

Dang HA, Lanjouw PF, Swinkels R (2014) Who remained in poverty, who moved up, and who fell down? An investigation of poverty dynamics in Senegal in the late 2000s. Policy research working paper 7141. World Bank, Washington, DC

Daniel VE, Florax RJGM, Rietveld P (2009) Flooding risk and housing values: an economic assessment of environmental Hazard. Ecol Econ 69(2):355-365

Datt G, Hoogeveen H (2003) El Niño or El Peso? Crisis, Poverty and Income Distribution in the Philippines. World Development, special issue: "Economic Crises, Natural Disasters, and Poverty." 31:1103-24. https://doi.org/10.1016/S0305-750X(03)00060-3

del Ninno C, Dorosh PA, Smith LC, Roy DK (2001) The 1998 Floods in Bangladesh: Disaster Impacts, Household Coping Strategies, and Response. Research Report No. 122. International Food Policy Research Institute, Washington, DC

Demirguc-Kunt A, Klapper L, Singer D, Ansar S, Hess J (2018) The global Findex database 2017: measuring financial inclusion and the Fintech revolution. The World Bank. https://oi.org/10.1596/978-1-4648-1259-0

Dercon S (2004) Growth and shocks: evidence from rural Ethiopia. J Dev Econ 74:309-329

Dercon S, Porter C (2014) Live aid revisited: long-term impacts of the 1984 Ethiopian famine on children. J Eur Econ Assoc 12:927-948. https://doi.org/10.1111/jeea.12088

Deryugina T (2016) The fiscal cost of hurricanes: disaster aid versus social insurance. National Bureau of Economic Research, Cambridge

Dollar D, Kraay A (2002) Growth is good for the poor. J Econ Growth 7:195-225. https://doi.org/10.1023 /A:1020139631000

Dollar D, Kleineberg T, Kraay A (2013) Growth still is good for the poor. Policy research working paper 6568. World Bank, Washington, DC

Durand-Lasserve A, Selod H, Durand-Lasserve M (2013) A systemic analysis of land markets and land institutions in west African cities: rules and practices - the case of Bamako, Mali. Policy research working paper 6687. World Bank, Washington, DC

Erman A, Motte E, Goyal R, Asare A, Takamatsu S, Chen X, Malgioglio S, Skinner A, Yoshida N, Hallegatte S (2020) The road to recovery: the role of poverty in the exposure, vulnerability and resilience to floods in Accra. Economics of Disasters and Climate Change, this issue

Erman A, Tariverdi M, Obolensky M, Hallegatte S (2019) Flooded in Dar Es Salaam - the role of poverty in disaster risk. Policy Research Working Paper 8976. The World Bank

Fagen PW (2006) Remittances in conflict and crises: how remittances sustain livelihoods in war, crises and transitions to peace. Policy Paper, International Peace Academy, New York, February

Fay, M. 2005. The urban poor in Latin America. Directions in Development-General, World Bank, Washington, DC

Felbermayr G, Gröschl J (2014) Naturally negative: the growth effects of natural disasters. Journal of Development Economics, special Issue: "Imbalances in Economic Development." 111:92-106. https://doi. org/10.1016/j.jdeveco.2014.07.004

Ferris E (2010) Natural Disasters, Conflict, and Human Rights: Tracing the Connections. Brookings InstitutionUniversity of Bern Project on Internal Displacement, March 3

Fuchs A (2014) Shocks and poverty in Haiti. Presentation at the Poverty and Climate Change in the Latin America and Caribbean Region Workshop, September 14

Gentilini U (2015) Safety nets in urban areas: emerging issues, evidence and practices. In: The state of social safety nets. World Bank, Washington, DC, pp 62-72

Gentle P, Thwaites R, Race D, Alexander K (2014) Differential impacts of climate change on communities in the middle hills region of Nepal. Nat Hazards 74:815-836. https://doi.org/10.1007/s11069-014-1218-0

Glave M, Fort R, Rosemberg C (2008) Disaster risk and poverty in Latin America: the Peruvian case study. Document prepared for the ISDR/RBLAC Research Project on Disaster Risk and Poverty 
Hallegatte S (2012) An exploration of the link between development, economic growth, and natural risk. Policy research working paper 6216 . World Bank, Washington, DC

Hallegatte S (2014) Natural disasters and climate change. Springer International Publishing, Basel

Hallegatte S (2017) A normative exploration of the link between development, economic growth, and natural risk. Economics of Disasters and Climate Change 1(1):5-31. https://doi.org/10.1007/s41885-017-0006-1

Hallegatte S, Vogt-Schilb A (2019) Are losses from natural disasters more than just asset losses?: the role of capital aggregation, sector interactions, and investment behaviors. In: Advances in Spatial Science, 15-42. Springer International Publishing. https://doi.org/10.1007/978-3-030-16237-5_2

Hallegatte S, Bangalore M, Nkoka FS (2015) Recent floods in Malawi hit the poorest areas: what this implies. Voices-Perspectives on Development http://blogs.worldbank.org/voices/recent-floods-malawi-hit-poorestareas-what-implies

Hallegatte S, Vogt-Schilb A, Bangalore M, Rozenberg J (2016a) Unbreakable: building the resilience of the poor in the face of natural disasters. The World Bank. https://doi.org/10.1596/978-1-4648-1003-9

Hallegatte S, Bangalore M, Bonzanigo L, Fay M, Kane T, Narloch U, Rozenberg J et al (2016b) Shock waves: managing the impacts of climate change on poverty. Climate change and development series. World Bank, Washington, DC

Hallegatte S, Bangalore M, Jouanjean MA (2016c) Higher losses and slower development in the absence of disaster risk management investments. Policy research working paper 7632. World Bank, Washington, DC

Hallegatte S, Fay M, Barbier EB (2018) Poverty and climate change: introduction. Environ Dev Econ 23(3):217233

Harris K, Keen D, Mitchell T (2013) When disasters and conflicts collide: improving links between disaster resilience and conflict prevention. Overseas Development Institute (ODI), London

Henry M, Spencer N, Strobl E (2019) The impact of tropical storms on households: evidence from Panel data on consumption. Oxf Bull Econ Stat 82:1-22. https://doi.org/10.1111/obes.12328

Hoddinott J (2006) Shocks and their consequences across and within households in rural Zimbabwe. J Dev Stud 42:301-321

Insurance Bureau of Canada (2015) The financial management of flood risk. An International Review: Lessons Learnt from Flood Management Programs in G8 Countries. Toronto

IPCC (Intergovernmental Panel on Climate Change) (2012) Special report on managing the risks of extreme events and disasters to advance Climate Change adaptation: summary for policymakers: a report of working groups I and II of the IPCC. Geneva

Jensen R (2000) Agricultural volatility and Investments in Children. Am Econ Rev 90:399-404. https://doi. org/10.1257/aer.90.2.399

Karim A, Noy I (2016) Poverty and natural disasters: a regression meta-analysis. Review of Economics and Institutions 7(2):26

Kinnan C, Townsend R (2012) Kinship and financial networks, formal financial access, and risk reduction. Am Econ Rev 102(3):289-293. https://doi.org/10.1257/aer.102.3.289

Klomp J, Valckx K (2014) Natural disasters and economic growth: a meta-analysis. Glob Environ Chang 26: $183-195$

Krishna A (2006) Pathways out of and into poverty in 36 villages of Andhra Pradesh, India. World Development, part special issue: "Corruption and Development: Analysis and Measurement." 34:271-88. https://oi. org/10.1016/j.worlddev.2005.08.003

Kuhn R (2009) Tsunami and conflict in Sri Lanka. Background paper for the Joint World Bank-UN Project on the Economics of Disaster Risk Reduction, Washington DC

Kunreuther H, Pauly S, McMorrow S (2013) Insurance and behavioral economics: improving decisions in the most misunderstood industry. Cambridge University Press, New York

Kuriakose AT, Heltberg R, Wiseman W, Costella C, Cipryk R, Cornelius S (2013) Climate-responsive social protection. Dev Policy Rev 31:o19-034. https://doi.org/10.1111/dpr.12037

Maccini S, Yang D (2009) Under the weather: health, schooling, and economic consequences of early-life rainfall. Am Econ Rev 99:1006-1026. https://doi.org/10.1257/aer.99.3.1006

Madajewicz M, Tsegay AH, Norton M (2013) Managing risks to agricultural livelihoods: impact evaluation of the Harita program in Tigray, Ethiopia, 2009-2012. Oxfam, London

Mbaiwa JE, Sakuze LK (2009) Cultural tourism and livelihood diversification: the case of Gcwihaba caves and XaiXai Village in the Okavango Delta, Botswana. J Tour Cult Chang 7(1):61-75

McCarthy N, Kilic T, de la Fuente A, Brubaker JM (2018) Shelter from the storm? Household-level impacts of, and responses to, the 2015 floods in Malawi. Economics of Disasters and Climate Change 2(3):237-258. https://doi.org/10.1007/s41885-018-0030-9

Mesfin W, Fufa B, Haji J (2011) Pattern, trend and determinants of crop diversification: empirical evidence from smallholders in eastern Ethiopia. Journal of Economics and Sustainable Development 2(8):78-89 
Mohapatra S, Joseph G, Ratha D (2009) Remittances and natural disasters: ex-post response and contribution to ex-ante preparedness. Policy research working paper 4972. World Bank, Washington, DC

Moore D, Niazi Z, Rouse R, Kramer B (2019) Building resilience through financial inclusion: a review of existing evidence and knowledge gaps. www.poverty-action.org

Morduch J (1995) Income smoothing and consumption smoothing. J Econ Perspect 9(3):103-114. https://doi. org/10.1257/jep.9.3.103

Narloch UG, Bangalore M (2016) Environmental risks and poverty: analyzing geo-spatial and household data from Vietnam. Policy research working paper 7763. World Bank, Washington, DC

Nguyen van K (2011) Building livelihood resilience in changing climate. Paper presented at Asia Regional Conference, Kuala Lumpur, Malaysia

Noack F, Wunder S, Angelsen A, Boerner J (2015) Responses to weather and Climate: a cross-section analysis of rural incomes. Policy research working paper 7478. World Bank, Washington, DC

Noji EK (2000) The public health consequences of disasters. Prehosp Disaster Med 15(4):147-157. https://doi. org/10.1017/s1049023x00025255

Noy I, Patel P (2014) Floods and Spillovers: Households after the 2011 Great Flood in Thailand. Working Paper Series No. 3609, School of Economics and Finance, Victoria University of Wellington

Noy I, W. duPont IV. (2018) The long-term consequences of disasters: what do we know, and what we still Don't. Int Rev Environ Resour Econ 12(4):325-354. https://doi.org/10.1561/101.00000104

ODI (Overseas Development Institute) and GFDRR (Global Facility for Disaster Reduction and Recovery) (2015) Unlocking the triple dividend of resilience - why investing in DRM pays off. http://www.odi. org/tripledividend

Opondo DO (2013) Erosive coping after the 2011 floods in Kenya. Int J Global Warm 5:452-466. https://doi. org/10.1504/IJGW.2013.057285

Owen S, Noy I (2019) Regressivity in public natural Hazard insurance: a quantitative analysis of the New Zealand case. Economics of Disasters and Climate Change 3(3):235-255. https://doi.org/10.1007/s41885019-00043-1

Park J, Hallegatte S, Bangalore M, Sandhoefner E (2015) The deck is stacked (and hot)? Climate Change, labor productivity, and developing countries. Policy research working paper 7479. World Bank, Washington, DC

Patankar A (2015) The exposure, vulnerability and adaptive capacity of households to floods in Mumbai. Policy research working paper 7481. World Bank, Washington, DC

Patankar A, Patwardhan A (2016) Estimating the uninsured losses due to extreme weather events and implications for informal sector vulnerability: a case study of Mumbai, India. Nat Hazards 80(1):285-310. https://doi.org/10.1007/s11069-015-1968-3

Pelling M (1997) What determines vulnerability to floods: a case study in Georgetown, Guyana. Int J Environ Probl 9:203-226

Perez-De-Rada E, Paz D (2008) Análisis de la relación entre amenazas naturales y condiciones de vida: El Caso de Bolivia. ISDR/RBLAC Research Project on Disaster Risk and Poverty

Porio E (2011) Vulnerability, adaptation, and resilience to floods and climate change-related risks among marginal, riverine communities in metro Manila. Asian J Soc Sci 39(4):425-445

Rabbani G, Rahman SH, Faulkner L (2013) Impacts of climatic hazards on the small wetland ecosystems (ponds): evidence from some selected areas of coastal Bangladesh. Sustainability 5:1510-1521. https://oi. org/10.3390/su5041510

Ranger N, Hallegatte S, Bhattacharya S, Bachu M, Priya S, Dhore K, Rafique F et al (2011) An assessment of the potential impact of climate change on flood risk in Mumbai. Climate Change 104:139-167

Reardon T, Taylor JE (1996) Agroclimatic shock, income inequality, and poverty: evidence from Burkina Faso. World Dev 24:901-914. https://doi.org/10.1016/0305-750X(96)00009-5

Rozenberg J, Hallegatte S (2017) Model and methods for estimating the number of people living in extreme poverty because of the direct impacts of natural disasters. Policy Research Working Paper. World Bank, Washington, DC

Rush JV (2018) The impact of natural disasters on education in Indonesia. Economics of Disasters and Climate Change 2(2):137-158. https://doi.org/10.1007/s41885-017-0022-1

Safir A, Piza SFA, Skoufias E (2013) Disquiet on the weather front: the welfare impacts of climatic variability in the rural Philippines. Policy Research Working Paper. World Bank, Washington, DC

Sanchez F, Calderon S (2014) Natural Disasters and Multidimensional Poverty in Colombia. Paper presented at the Workshop on Climate Change and Poverty in the Latin America Region. World Bank, Washington, DC

Scussolini P, Aerts J, Jongman B, Bouwer L, Winsemius HC, de Moel H, Ward PJ (2016) FLOPROS: an evolving global database of flood protection standards. Nat Hazards Earth Syst Sci 16(5):1049-1061. https://doi.org/10.5194/nhess-16-1049-2016

Skidmore M, Toya H (2002) Do natural disasters promote long-run growth? Econ Inq 40:664-687 
Strobl E (2010) The economic growth impact of hurricanes: evidence from U.S. coastal counties. Rev Econ Stat 93:575-589. https://doi.org/10.1162/REST_a_00082

Sur D, Dutta P, Nair GB, Bhattacharya SK (2000) Severe cholera outbreak following floods in a northern district of west Bengal. Indian J Med Res 112(NOV.):178-182

Tesliuc E, Lindert K (2003) Vulnerability: a quantitative and qualitative assessment. Working paper 36209. World Bank, Washington, DC

UNISDR (United Nations Office for Disaster Risk Reduction) (2009) United Nations global assessment report on disaster risk reduction. UNISDR, Geneva

Peter G von, von Dahlen S, Saxena SC (2012) Unmitigated Disasters? New Evidence on the Macroeconomic Cost of Natural Catastrophes. BIS Working Paper No. 394, Bank for International Settlements, Basel, Switzerland

Walsh B, Hallegatte S (2020) Measuring natural risks in the Philippines: socioeconomic resilience and wellbeing losses. Economics of Disasters and Climate Change. https://doi.org/10.1007/s41885-019-00047-x

Winsemius HC, Jongman B, Veldkamp TIE, Hallegatte S, Bangalore M, Ward PJ (2018) Disaster risk, climate change, and poverty: assessing the global exposure of poor people to floods and droughts. Environment and Development Economics, March, 1-21. https://doi.org/10.1017/S1355770X17000444

Wodon Q, Liverani A, Joseph G, Bougnoux N (2014) Climate Change and migration: evidence from the Middle East and North Africa. World Bank, Washington, DC

World Bank (2013) World development report 2014: risk and opportunity-managing risk for development. World Bank, Washington, DC

World Bank (2015) Can remittances help promote consumption stability? (global economic prospects). World Bank, Washington, DC

Wu T (2006) The role of remittances in crisis: an Aceh research study. Overseas Development Institute, London Yamano T, Alderman H, Christiaensen L (2005) Child growth, shocks, and food aid in rural Ethiopia. Am J Agric Econ 87:273-288. https://doi.org/10.1111/j.1467-8276.2005.00721.x

Yang D, Choi H (2007) Are remittances insurance? Evidence from rainfall shocks in the Philippines. World Bank Econ Rev 21:219-248

Yonson R (2018) Floods and pestilence: diseases in Philippine urban areas. Economics of Disasters and Climate Change 2(2):107-135. https://doi.org/10.1007/s41885-017-0021-2

Publisher's Note Springer Nature remains neutral with regard to jurisdictional claims in published maps and institutional affiliations. 